\title{
Factors Affecting Early Marriage in Central Java Province
}

DOI: https://doi.org/10.47175/rissj.v1i2.61

\section{| Urip Tri Wijayanti |}

\author{
National Population and \\ Family Planning Board \\ (BKKBN), Center Java \\ Province, Indonesia
}

haidar1602@yahoo.co.id

\begin{abstract}
BKKBN provides an ideal age for marriage, namely 20 years for women and 25 years for men. These ways are steps to avoid divorce, domestic violence and early marriage. The reality is that the cases of early marriage still happen. One of them is in the province of Central Java. The purpose of this study is to analyze the description of perpetrators' early marriage and the factors affecting it. This research uses the quantitative method with cross sectional study design, using IDHS raw data for 2017. The results showed that most perpetrators of early marriage at the age of 4549 years 276 people (22.9\%), first married at the age of $15-19$ years 1104 (91.8\%), living in rural areas 723 people (60.1\%), low education only graduated from elementary school 503 people (41.8\%), covered 764 people (63.5\%) with jobs as sales 251 people (32.9\%) and wealth index on the index lower middle 333 people (27.7\%). The affecting factor early marriage is education level. While the factors of residence, wealth index and employment status do not affect. BKKBN recommendation and the ministry of education coordinate with each other in promoting twelve-year compulsory education, through socialization by Family Planning Counseling or always call as PKB and through popular media so that the whole community gets information about the importance of education so they don't get married early./ device has increased from $49.42 \%$ in 2017 to $56.25 \%$ in 2019.
\end{abstract}

KEYWORDS

Factors; influence; early marriage.

\section{INTRODUCTION}

Java Province is the third largest province in terms of population. Central Bureau of Statistics (or always calls as BPS in Indonesia) recorded that in 2018 the population of Central Java Province would be 34.26 million people. This number was $12.93 \%$ of the population of Indonesia. It is projected that in 2035 the number will reach 37.5 million. The projected figure can be higher if the number of marriages continues to increase.

Marriage according to Law number 1 of 1974 concerning marriage is a physical bond between a man and a woman as husband and wife with the aim of forming a happy and eternal family (household) based on the Godhead of the Almighty. According to this law marriage is permitted if the man has reached the age of 19 years and the woman has reached the age of 16 years. This age limit was then revised through Law number 16 of 2019, where the age limit for both men and women becomes 19 years. BKKBN make the marriage age maturity program that provides an ideal marriage limit for women of at least 20 years and 25 years for men. This age limit is considered to be ready to face family life in terms of health and emotional development (BKKBN, 2017). The age limit for marriage is one of the steps of the government to prevent divorce, under-age marriage and domestic violence.

In fact early marriage under the minimum limits age still exists. In the province of Central Java, married women under the age of 20 continue to occur, even after the change in age 
restrictions on marriage, marriage dispensation requests in Central Java have increased. Data in the Central Java Religious Court noted an increase in dispensation of $286.2 \%$ (F\&N, 2019). Long before the data collected by the Indonesian Women's Coalition (KPI), during 2016 there were 30,128 underage women in Central Java applying for dispensation to be able to get married, of which only about 2,900 were approved. Means there are around 30,000 children who get married by breaking up age or under the hand (Saputra, 2017). In 2019 there were 30 thousand Representative BKKBN data in Central Java Province, of which 10 percent were given dispensation by the Religious Courts office, or only three thousand (Tulus, 2019)

Even though doing marriage at a young age has various impacts. The results of studies in several countries state such as; In Bangladesh Field Studies et al in Djamilah and Reni Kartikawati (2014) high school dropouts occurred, subordination in the family, the risk of domestic violence, lack of control over reproductive health, and a high chance of maternal death. Then, in Ethiopia has an impact on marital instability, low health status, low education and school dropouts, too many children, inequality of women's status and child welfare (Djamilah and Reni Kartikawati, 2014). Findings of the Indonesian Plan and the Center of Population and Policy Studies (PSKK) of University of Gajah Mada (UGM) (PSKK UGM and Plant Indonesia, 2011) have an impact on high-risk pregnancies, mental health threats, domestic violence and reproductive health problems of young marriages are also prone to divorce. The data of Central Bureau Statistics (BPS) 2010 shows the highest divorce cases affecting the age group of 20-24 years with the age of marriage not even five years (Yuliani, 2018).

There have been many studies analyzing the factors that influence early marriage. Ayuning Aulia, et al (2015) found factors of education, motivation to continue education, media, pornography and knowledge. Kumalasari (2014) found socio-cultural, economic, educational, religious factors, difficult to find work, mass media, views and beliefs as well as parents.

This study aims to analyze the picture of early marriage perpetrators in women and the factors that influence it. Factors of residence, wealth index, education, employment status are factors that will be discussed in this study.

\section{RESEARCH METHODS}

This research is a quantitative study with a cross sectional study design (cross section) to determine the factors that influence women's early marriage. The data used in raw data of Indonesia Demographic and Health Survey 2017 is Central Java Province. Respondents in this study were women of childbearing age who were first married under the age of 20 years. The number of respondents who met the requirements was 1203 people. The data used are as follows: age at first marriage (V 511), current age (V 013), residence (V 025), education level (V 149), employment status (V 716), wealth index (V 190).

Data processing was carried out using the SPSS 22 program. After that it was analyzed, covering the characteristics of each research variable with the frequency distribution displayed in the percentage of each data group. Furthermore, bivariate analysis is used to see the relationship between the independent variable and the dependent variable using the chi square significance test (comparing categorical variables) with a 95\% confidence level, if a $\mathrm{P}$ value of $\leq 0.05$ means that Ho is rejected (there is a relationship) and if $\mathrm{P} \geq 0,05$ means Ho is accepted (no relationship). According to Enterprise Jubilee (Enterprise, 2018) chi square is used to look for relationships between variables but do not see how big the relationship. 


\section{RESULT AND DISCUSSION}

According to Santoso (2014) guidelines or basis for decision making in the chi square test can be done by looking at the value of the "Chi Square Test" output table from the results of SPSS data processing. In making decisions for this square test we can be guided by two things, namely comparing between Asymp Sig value and with a critical limit of 0.05 or can also be compared by calculating the calculated chi square value with the value of the chi square table at a significance of $5 \%$. So in this study the decision making is based on the significance value (Asymp. Sig)

- Asymp Sig ( 2 sided) value $<0.05$, it means that Ho is rejected and Ha is accepted

- Asymp Sig (2 sided)> 0.05 means that Ho is accepted and Ha is rejected

Statistical results

Table 1. First Marriage Age Cross Table with respondent characteristics

\begin{tabular}{|c|c|c|c|c|c|c|c|c|c|c|c|c|}
\hline \multirow{3}{*}{ Variable } & \multicolumn{10}{|c|}{ The First Age to Marry/ Early Marriage } & \multirow{3}{*}{ Total } & \multirow{3}{*}{$\begin{array}{c}P \\
\text { Value }\end{array}$} \\
\hline & \multicolumn{2}{|c|}{ 10-11 } & \multicolumn{2}{|c|}{ 12-13 } & \multicolumn{2}{|c|}{ 14-15 } & \multicolumn{2}{|c|}{ 16-17 } & \multicolumn{2}{|c|}{ 18-19 } & & \\
\hline & $\mathbf{N}$ & $\%$ & $\mathbf{N}$ & $\%$ & $\mathbf{N}$ & $\%$ & $\mathbf{N}$ & $\%$ & $\mathbf{N}$ & $\%$ & & \\
\hline City & 4 & 0.8 & 12 & 2.5 & 59 & 12.3 & 162 & 33.8 & 243 & 50.7 & $480(100 \%)$ & 0.135 \\
\hline Village & 5 & 0.7 & 29 & 4 & 94 & 13 & 281 & 38.8 & 314 & 43.4 & $723(100 \%)$ & \\
\hline Bottom & 3 & 1.7 & 7 & 3.9 & 23 & 12.8 & 74 & 41.3 & 72 & 40.2 & $179(100 \%)$ & 0.260 \\
\hline Middle bottom & 4 & 1.2 & 11 & 3.3 & 48 & 14.4 & 132 & 39.6 & 138 & 41.4 & $333(100 \%)$ & \\
\hline Middle & 0 & 0 & 13 & 4.3 & 35 & 11.6 & 109 & 36 & 146 & 48.2 & $303(100 \%)$ & \\
\hline Middle top & 1 & 0.4 & 7 & 2.7 & 33 & 12.6 & 84 & 32.1 & 137 & 52.3 & $262(100 \%)$ & \\
\hline Top & 1 & 0.8 & 3 & 2.4 & 14 & 11.1 & 44 & 34.9 & 64 & 50.8 & $126(100 \%)$ & \\
\hline Law education & 9 & 0.8 & 40 & 3.8 & 149 & 14.1 & 410 & 38.9 & 447 & 42.4 & $055(100 \%)$ & 0.000 \\
\hline High education & 0 & 0 & 1 & 0.7 & 4 & 2.7 & 33 & 22.3 & 110 & 74.3 & $148(100 \%)$ & \\
\hline Work & 6 & 0.8 & 31 & 4.1 & 104 & 13.6 & 280 & 36.6 & 343 & 44.9 & $764(100 \%)$ & 0.250 \\
\hline Not work & 3 & 0.7 & 10 & 2.3 & 49 & 11.2 & 163 & 37.1 & 214 & 48.7 & $439(100 \%)$ & \\
\hline
\end{tabular}

Before discussing the relationship of each variable, a description of the respondent's age at first marriage and the respondent's age at the time of the study is presented.

\section{Age at first marriage}

Table 2. Age of Respondents when first married

\begin{tabular}{lrr}
\hline Age & $\mathbf{N}$ & $\boldsymbol{\%}$ \\
\hline 10-14 year & 99 & 8,2 \\
15-19 year & 1104 & 91.8 \\
\hline Total & 1203 & 100 \\
\hline
\end{tabular}

Table 2. Shows $1104(91.8 \%)$ respondents were married at vulnerable ages 15-19 years, while 99 people (8.2\%) married at vulnerable ages 10-14 years. all respondents married at the age that is not recommended in terms of health and are still far from the marriage age maturity program (PUP) BKKBN.

In health, the recommended age for women to get married is over 20 years. Because of early pregnancy has a great opportunity for the risk of childbirth and contributes greatly to an increase in the Maternal Mortality Rate (MMR) (BKKBN: 2004). Even according to the results of an analysis conducted by Menkokesra related to the high maternal mortality rate, around 82 percent of deaths occur in young people less than 15 years and between 15 and 20 years. The more early marriage will also have an impact on the high fertility, because it has a longer period to get pregnant and give birth than married women at the age of 20 years and over.

According to the BKKBN Marriage Age Maturity Program (BKKBN, PIK R/Student Management Technical Curriculum for Management, Peer Educators and PIK Teen/Student Peer Counselors, 2013) the ideal age for married women is at least 20 years and 25 years for 
men. This age limit is deemed ready both in terms of health and emotional development to deal with family life. Actually the age of marriage doesn't only delay marriage until a certain age, but try to make the first pregnancy occur at a fairly mature age.

In terms of education, vulnerable people aged 10-14 years are still in elementary school until junior high school. That means respondents who were married at that age in education have not yet completed the 12-year compulsory education that is encouraged by the government. The lack of education makes thinking patterns less widespread and one of the originators of young marriage decisions.

\section{Current Respondent Age}

Table 3. Current Age of Respondents

\begin{tabular}{lrr}
\hline Age & N & \% \\
\hline 15-19 Year & 33 & 2.7 \\
20-24 Year & 146 & 12.1 \\
25-29 Year & 137 & 11.4 \\
30-34 Year & 153 & 12.7 \\
35-39 Year & 231 & 19.2 \\
40-44 Year & 227 & 18.9 \\
45-49 Year & 276 & 22.9 \\
\hline Total & 1203 & 100.0 \\
\hline
\end{tabular}

Table 3. Shows that the most respondents at present are the range of age 45-49 years 276 people (22.9\%), then age 35-39 years 231 people (19.2\%) and the smallest at the age of 1519 years 33 people $(2.7 \%)$. Referring to the reproductive phase of women at age $<20$ years women must postpone pregnancy and marriage, ages 20-35 the period of spacing pregnancy with the use of contraceptives and age $>35$ women are recommended to terminate the pregnancy. See data table 2 means that as many as 33 people $(2.7 \%)$ of respondents must postpone pregnancy and then 436 people $(36 \%)$ of respondents in the spacing phase of pregnancy and 734 people $(61 \%)$ in the phase of terminating a pregnancy. In all phases, BKKBN must move from providing Information and Education Communication (IEC). IEC to delay pregnancy, spell pregnancy, terminate pregnancy, IEC about various types of contraception, the form, effectiveness and shortcomings of each contraceptive device and follow up by providing family planning services.

A more complete picture of the results of the research is presented in the following discussion;

\section{Relationship of residence with age of first marriage}

Table 4. Shelter

\begin{tabular}{lrr}
\hline Area & $\mathbf{N}$ & $\boldsymbol{\%}$ \\
\hline City & 480 & 39.9 \\
Village & 723 & 60.1 \\
\hline Total & 1203 & 100.0 \\
\hline
\end{tabular}

Table 4. Shows 723 people (60.1\%) live in rural areas and 480 people $(39.9 \%)$ live in urban areas. Looking at the characteristics based on the residence more live in rural areas than in urban areas. Rural communities have their own peculiarities in terms of social interaction. They are more intensive with each other so they know each other. Getting to know each other makes them one of kinship ties, living with mutual cooperation and having strong solidarity. However when the lack of education and the amount of time at home makes a great opportunity for women to decide to get married young. Stigma of a spinster and fear 
of behavior is not vague still attached to women who until the age of 20 years and over are not married. This is a driving force to get married soon.

Based on the calculation results obtained sig value is 0.135 (table 1) so the value of sig> 0.05 so that $\mathrm{H} 0$ is accepted means that there is no relationship between residence and age of marriage. These results differ from the results of Handayani and Ekawati's research (Sarah Handayani and Rindang Ekawati, 2015) according to her, the majority of urban respondents have a significant relationship with early marriage. These characteristics are different from this study, in terms of the characteristics of the majority of respondents living in rural areas. So this difference in characteristics makes the difference in results between the relationship between residence and age of first marriage.

\section{Relationship of education level with age of first marriage}

Table 5. Education Level

\begin{tabular}{lll}
\hline Education Level & N & \% \\
\hline Non-Schooling & 24 & 2.0 \\
Not Graduating Primary School & 138 & 11.5 \\
Graduating Primary School & 503 & 41.8 \\
Not Graduating Senior High & 390 & 32.4 \\
School & 142 & 11.8 \\
$\begin{array}{l}\text { Graduating School } \\
\text { College }\end{array}$ & 6 & 0.5 \\
\hline Total & 1203 & 100.0 \\
\hline
\end{tabular}

Table 5 Shows that the educational distribution of respondents varies, from the lowest level of non-schooling to the highest level of completion of college. The result is that in general respondents only graduated from elementary school is 503 people (41.8\%) and at least tertiary institutions were 6 people $(0.5 \%)$. These results indicate that educationally the respondents have low education.

Education is related to the mindset, perception and behavior of the community is indeed very significant, in the sense that the higher the level of one's education the more rational in making various decisions (Anita Lontaan, 2014). Related to the decision to marry young happens because of low education make it less rational to marry young. Fear of getting labeled spinster, unsold, ashamed because many friends who are married, forced by parents etc. is a thought that is less rational than health considerations that are not yet ideal for pregnancy and childbirth, are not yet economically established, still pursuing ideals, etc. emotional considerations will be more rational in the basis of young married decision making.

Prevention is carried out so that adolescents do not marry young according to NaGeo (2019) by facilitating and access to formal education inclusively for girls and boys, then socializing and educating about sexual and reproductive rights and health for children and adolescents as well as advocacy and promotion of gender equity and participation at the grassroots level. This strategy is seen as quite effective in equipping adolescents as a preventive measure. While on the other hand the existence of strengthening support from decision makers will also effectively fortify adolescents not to marry young. Concrete steps with programs that are more effective for adolescents, one of which is the Genre (Planning Generation) program driven by BKKBN. This program is a youth coaching program that aims to increase the knowledge and skills of adolescents through the PIK R/M (Youth/ Student Information and Counseling Center) in order to realize the strong adolescent. The strong adolescents is adolescents who behave in a healthy manner, delaying the age of marriage and have a life planning life. This activity is through two activities. In adolescence through PIK R/ M then in their families through the BKR (Adolescent Family Development) 
group. BKR is a group of families with teenagers, the group aims to increase knowledge, insight and guidance for families in educating, fostering and directing their teenage children to become independent teenagers and have plans for their future.

The BKKBN study (2017) on PIK-R/M states that PIK-R has a role in changing the average age limit of first-marriage to become more mature (studies on adolescents before and after becoming members of PIK-R). It means that adolescents who are members of the PIK-R/M have good enough knowledge about the ideal limits of marriage. This knowledge is implemented in young unmarried behavior.

Based on the calculation results obtained sig value of 0,000 (table 1) so the value of sig $<0.05$ so that $\mathrm{H} 0$ is rejected means that there is a relationship between the level of education with the age of first marriage. These results are in line with research by Handayani and Ekawati (Sarah Handayani and Rindang Ekawati, 2015). Education according to Dimyanti and Mudjiono (Dimyati and Mujiono, 2006) can improve one's ability in the cognitive, affective and psychomotor domains. The cognitive domain includes knowledge, understanding, can apply, carry out analysis, synthesis, and evaluate. The affective domain includes accepting, participating, determining attitudes, organizing and shaping patterns of life. Related to the decision to get married at a young age, in the cognitive domain the community gets some knowledge about the first marriage age limit for both men and women in terms of religion, law and health, secondly the preparation of family life from the economic, health, psychological side, education, religion and social, the three impacts of getting married young both for individuals, couples, parents and extended families, fourth, understanding family functions. Furthermore, all of the community's knowledge responds well and some are not good. For those who respond positively, he will determine the attitude to not marry young and manifest in the behavior of delaying until the ideal age for marriage. In the process of waiting, all preparations are carried out starting from healthy, economy, psychological etc. so that they are mature and ready to form a harmonious family.

\section{Employment relationship with age of first marriage}

Table 6. Job Status and Type

\begin{tabular}{lrr}
\hline Job Status & N & \% \\
\hline Work & 764 & 63.5 \\
Jobless & 439 & 36.5 \\
\hline Job & $\mathrm{N}$ & $\%$ \\
\hline Professional/technician & 6 & 0.8 \\
Manager and administration & 1 & 0.1 \\
Clerical & 6 & 0.8 \\
Sales & 251 & 32.9 \\
Service provider & 131 & 17.1 \\
Farmer & 195 & 25.5 \\
Industrial Worker & 174 & 22.8 \\
\hline Total & 764 & 100.0 \\
\hline
\end{tabular}

Respondents have a greater likelihood of working, as many as 764 people $(63.5 \%)$. With the first type of work as sales, there were 251 people (32.9\%), the second was 195 people in agriculture (25.5\%) and the third was industry workers 174 (22.8). Teenage girls who work will certainly be busy with their activities, so the thought of getting married is somewhat sidelined, they are busy pursuing careers to become economically independent women.

Based on the calculation results obtained sig value of 0.250 (table 1) so the value of sig> 0.05 so that $\mathrm{HO}$ is accepted means that there is no relationship between work status and age at first marriage. This result is different from the findings of Handayani and Ekawati (2015), there is a relationship between work status and age at first marriage with most respondents 
not working. Different characteristics in this study are $63.5 \%$ respondents worked with the most types of work as sales $32.9 \%$ (table 6).

\section{The relationship of wealth index with age of first marriage}

Table 7. Wealth Index

\begin{tabular}{lrr}
\hline Wealth Index & $\mathbf{N}$ & $\boldsymbol{\%}$ \\
\hline Bottom & 179 & 14.9 \\
Middle bottom & 333 & 27.7 \\
Middle & 303 & 25.2 \\
Middle top & 262 & 21.8 \\
Top & 126 & 10.5 \\
\hline Total & 1203 & 100.0 \\
\hline
\end{tabular}

Table 7 Shows that the respondents' wealth index varied, with the most results being in the lower middle index as many as 333 people (27.7\%) and at least being in the top wealth index which was 126 people $(10.5 \%)$.

Based on the calculation results obtained sig value of 0.260 (table 1) so the value of sig> 0.05 so that $\mathrm{H} 0$ is accepted means that there is no relationship between the wealth index with the age of first marriage. Means the decision to get married is not based on the background of the wealth index. It may be because in general respondents in the middle to lower wealth index and have a job. So it does not affect the decision to get married the first time.

\section{CONCLUSION}

Based on statistical analysis of the data of Indonesia Demographic Health Survey 2017 in Central Java Province, it was concluded that the number of respondents married below the age of 20 years was 1203 . The description of early marriage perpetrators as follows first when the study was conducted; the first, they were mostly at the vulnerable age of 45-49 years as many as 276 people $(22.9 \%)$. The second, the first married is at the age of 15-19 years as many as $1104(91.8 \%)$. Third, live in rural areas, 723 people (60.1\%). Fourth, education is still low, most only graduated from elementary school, 503 people (41.8\%). The last, $(32.9 \%)$ people of the wealth index were mostly in the lower middle index, 333 people $(27.7 \%)$. Then the factors that influence early marriage are the level of education. While the factors of residence, wealth index and employment status do not affect.

BKKBN suggestion and the ministry of education coordinate with each other in promoting the twelve-year compulsory education program launched by the government, both through socialization conducted by PKB and in popular media so that the whole community gets information about the importance of education. Through education it opens people's insights and understanding to not get married at an early age.

\section{ACKNOWLEDGMENT}

The author would like to thank the Representative of BKKBN Central Java Province for providing the opportunity to researchers, also thanks BKKBN for providing raw data for Indonesia Demographic Health Survey 2017, Central Java Province.

\section{REFERENCES}

Anita Lontaan, d. (2014). Faktor-Faktor Yang Berhubungan Dengan Pemilihan Kontrasepsi

Pasangan Usia Subur Di Puskesmas Damau Kabupaten Talaud. Jurnal Ilmiah Bidan. Ayuning Aulia, dkk. (2015). Faktor-Faktor Yang Mempengaruhi Perkawinan Usia Muda Pada Remaja Putri Usia 10-19 Tahun di Kecamatan Selakau Kabupaten Sambas. Jurnal Mahasiswa dan Penelitan Kesehatan JuMantik. 
BKKBN. (2013). Kurikulum Diklat Teknis Pengelolaan PIK R/Mahasiswa Bagi Pengelola, Pendidik Sebaya dan Konselor Sebaya PIK Remaja/Mahasiswa. Jakarta: BKKBN.

BKKBN. (2017). Peranaan Pusat Informasi dan Konseling (PIK-R) dalam Menurunkan Angka Kelahiran Usia Remaja dan Pendewasaan Usia Perkawinan. Jakarta: BKKBN.

Dimyati dan Mujiono. (2006). Belajar dan Pembelajaran. Jakarta: PT Rineka Cipta.

Djamilah dan Reni Kartikawati. (2014). Dampak Perkawinan Anak Di Indonesia. Jurnal Studi Pemuda .

Enterprise, J. (2018). SPSS Komplit Untuk Mahasiswa. Jakarta: PT Elex Media Komputindo.

Kumalasari. (2014). Kesehatan reproduksi untuk mahasiswa kebidanan dan keperawatan. Jakarta : Salemba Medika.

NaGeo. (2019). Webminar Upaya Remaja Untuk Tidak Menikah Muda.

PSKK UGM dan Plant Indonesia. (2011). Laporan Akhir Pernikahan Anak di Indonesia Tahun 2011. Yogyakarta: PSKK UGM.

Santoso, S. (2014). Santoso, SiStatistik Parametrik Konsep dan Aplikasi dengan SPSS. Jakarta: PT Elex Media Komputindo.

Saputra, I. Y. (2017). https://www.solopos.com/pernikahan-dini-30-128-perempuan-dijateng-nikah-di-bawah-umur-870443. Retrieved from https://www.solopos.com/pernikahan-dini-30-128-perempuan-di-jateng-nikah-dibawah-umur-870443: https://www.solopos.com

Sarah Handayani dan Rindang Ekawati. (2015). determinan faktir Pernikahan Dini Perempuan Di Provinsi Jawa Barat (Analisis Lanjut Data SDKI 2012). Jurnal Kependudukan dan Keluarga Berencana, 13-20.

Yuliani, P. A. (2018). https://mediaindonesia.com/read/detail/181744-pernikahan-remajarawan-perceraian. Retrieved from https://mediaindonesia.com/read/detail/181744pernikahan-remaja-rawan-perceraian: https://mediaindonesia.com 